international agreement through the good offices and possible participation of the Government of the United States.

Chandler P. Anderson

\title{
THE NEW CUBAN TREATY
}

On May 29, 1934, the plenipotentiaries, Mr. Hull, Secretary of State, and Mr. Welles, Assistant Secretary of State, on the part of the United States, and Ambassador Marquez Sterling, on the part of Cuba, signed in Washington a treaty modifying the Treaty of Relations of May 22, 1903, between the two countries. The Senate gave its prompt and unanimous approval to the treaty on May 31. Only one or two Senators questioned the wisdom of the pact, but did not feel like objecting seriously. In Cuba, the President and Council of Secretaries (Cabinet) ratified the treaty pursuant to the provisional constitution of February 3, 1934. Ratifications were exchanged at Washington on June 9, on which date the treaty went into effect. ${ }^{1}$

The Treaty of 1903 has been criticized in Cuba and Latin America generally as establishing a protectorate over the island by incorporating the terms of the Platt Amendment to the Act of Congress of March 2, 1901. The Platt Amendment provided that the future relations of the two countries should be defined in the Constitution of Cuba substantially as follows:

(1) The Government of Cuba shall never enter into any treaty with a foreign Power which will impair the independence of Cuba, and shall not allow any foreign Power to obtain lodgment or control in any portion of the island for colonization, military or naval purposes, or otherwise.

(2) The Government of Cuba shall not contract any public debt of which the ordinary net revenues shall be inadequate to pay the interest and sinking fund.

(3) The United States may exercise the right to intervene for the preservation of Cuban independence and the maintenance of a government adequate for the protection of life, property and individual liberty, and for discharging the obligations assumed by the United States in the Treaty of Paris and now to be undertaken by the Government of Cuba.2

(4) All acts of the United States during military occupancy are ratified.

(5) The Government of Cuba will undertake the sanitation of the cities of the island.

(6) The title to the Isle of Pines shall be left to future adjustment.

1 The treaty is printed in the Supplement to this Journal, p. 97.

2 The obligations of the United States mentioned in Paragraph 3 refer to those in the Treaty of Peace of 1898 , and apparently mean that the rights therein granted to Spain in respect of Cuba shall be carried out by the Cuban Government; such as, obtaining the release of Spanish prisoners in the hands of insurgents in Cuba, allowing Spain to obtain copies of official documents in the archives, allowing Spanish subjects to acquire nationality under certain conditions, granting them rights of religion, access to the courts, continuation of judicial proceedings, and continuation of property rights, free importation of scientific, literary and artistic works for ten years, establishment of consular offices, etc. 
(7) To enable the United States to maintain the independence of Cuba and the people thereof, as well as for its own defense, Cuba will sell or lease to the United States lands for coaling or naval stations at points to be agreed upon.

(8) The Government of Cuba will embody the foregoing provisions in a permanent treaty with the United States.

The Platt Amendment was accepted and incorporated in the Cuban Constitution after bitter opposition in the Constitutional Convention, and after a protest to President McKinley by a Cuban mission to the United States. The final acceptance by the Cubans followed the famous "Root interpretation" in a letter by him, as Secretary of War, to General Leonard Wood, to the effect that the right of intervention given to the United States by Paragraph 3 of the Platt Amendment was not synonymous with intermeddling or interference with the affairs of the Cuban Government. Before the United States withdrew from Cuba, the treaty of May 22, 1903, above-mentioned, containing the Platt Amendment, was concluded.

The Platt Amendment aimed to secure the independence of Cuba, a stable government, financial solvency, adequate naval bases, and sanitary conditions on the island. Whatever difference of opinion there may be as to the wisdom of the Platt Amendment, the authors undoubtedly intended it to be helpful to Cuba, which was inexperienced in self-government and subject to a state of disorder. Moreover, it gave an assurance to the world that order would be maintained and life and property protected in the new Republic.

The contention has been made that the Platt Amendment has failed in maintaining a solvent government and a government adequate for protection of life and property; and that besides it has prevented the Cubans from taking the responsibility of self-government and attaining maturity in state-craft, for Uncle Sam would come to the rescue. Under the Platt Amendment there was one formal intervention by the United States, lasting from 1906 to 1909, with all the train of criticism and a brood of difficult problems for future adjustment. In 1912, United States troops were landed for a few weeks at the eastern end of the island on the occasion of an insurrection, and again in March 1917, and later, when Cuba entered the war, troops were landed by arrangement for training purposes and remained until the close of the war. Subsequently, General Crowder visited the island in 1921-1923, as special representative of the United States, to recommend certain financial and other reforms. Some of these were adopted, at least for the time being, but later other policies prevailed. Cuba's total debt, internal and external, ran up to well over $\$ 200,000,000$. On the whole, however, the conservatives, including the business men, appeared to favor the Platt Amendment with the possibility of intervention, as conducive to order and enterprise, while the liberals chose the ideal of unlimited independence and sovereignty.

Meanwhile, American interests in the Caribbean area had expanded greatly in other directions. In the same year as the old treaty with Cuba, the United States acquired the Panama Canal Zone for the construction of an inter- 
oceanic canal, together with certain lands at the entrance, at the same time guaranteeing the independence of Panama. Under a treaty of 1907 , the United States assumed administration of the finances of the Dominican Republic, and in 1914, the United States acquired canal and naval-base rights in Nicaragua, including the right to protect them. In 1915, the United States by treaty took over practically the financial and political control of Haiti (soon to be ended), and in 1916-1917, purchased the Virgin Islands from Denmark.

Along with the growth of the political interests of the United States in the Caribbean area went an increase of American capital by way of loans and commercial investments. This expansion has been unfavorably viewed by the many Latin American States as indicating, by acts which speak louder than words, imperialistic policies and ulterior motives on the part of this country. And yet it is fair to say that had these political and commercial ties fallen into the hands of European countries, the probability is that they would not have been so leniently handled in time of distress as they have been and will be by the United States. But as Daniel Webster once said: "No matter how easy may be the yoke of a foreign Power, no matter how lightly it sits upon the shoulder, if it is not imposed by the voice of his own nation and of his own country, he will not, he cannot, and he means not to be happy under its burden."

For a long time the student movement against Machado had been smoldering under his persecution, but apparently, at first, had no definite program beyond his removal from the presidency. Subsequently, however, it adopted certain reform features of other revolutionary movements, under the slogan of "Cuba for the Cubans," which included the restitution of complete national sovereignty. The program demanded a modern Cuban constitution, the abrogation of the Platt Amendment and a revision of the Reciprocity Treaty with the United States.

The new administration of President Roosevelt early endeavored to allay the Latin American apprehensions of American motives. In his inaugural address, he said, "I would dedicate this nation to the policy of the good neighbor-the neighbor who resolutely respects himself and because he does so, respects the rights of others-the neighbor who respects his obligations, respects the sanctity of his agreements in and with a world of neighbors." This idea was reiterated in his address on Pan American Day, April 12, 1933, and he added a corollary, namely, that none of the states of America may acquire territory at the expense of any neighbor. In his message to the World Economic and Disarmament Conference on May 16, 1933, President Roosevelt called upon the nations, among other things, to "agree that they will send no armed forces of whatsoever nature across their frontiers." To the Latin Americans these were only like the beautiful platitudes of the past, more honored in the breach than the observance. They waited to see words translated into actions. They wanted a sign, but they were to behold a miracle wrought. 
When the pent-up revolution broke out in Cuba, Machado fled, and vengeful disorder spread through the island. President Roosevelt, after conferring with Latin American diplomats in Washington, dispatched warships to Cuba, but directed that no marines should be landed save in the gravest emergency. He let it be known that "no possible question of intervention" under the Platt Amendment "is intended by this precautionary step."

Subsequently, President Roosevelt indicated that the United States was prepared to coöperate for Cuba's economic restoration in respect of agrarian, financial and tariff problems. In November last, he also expressed a wish to commence negotiations for a modification of the treaties with Cuba. This was followed by his declaration of December 28th that-

the definite policy of the United States from now on is one opposed to armed intervention.

The maintenance of constitutional government in other nations is not a sacred obligation devolving upon the United States alone. The maintenance of law and the orderly processes of government in this hemisphere is the concern of each individual nation within its own borders first of all. It is only if and when the failure of orderly processes affects the other nations of the continent that it becomes their concern; and the point to stress is that in such an event it becomes the joint concern of a whole continent in which we are all neighbors.

As a climax to the demands of the revolution and the good-neighbor policy of the President, came the negotiations for the new treaty of relations recently ratified. The new treaty of 1934 terminates the entire treaty of 1903, in Article 1, and then proceeds to preserve certain of the rights therein stipulated. In Article 2, all acts effected in Cuba by the United States during its military occupancy up to May 20,1902, are confirmed, and rights arising therefrom are to be maintained and protected. By Article 3, the two agreements of 1903 in regard to the naval station at Guantanamo are continued in force on the same conditions; As the agreements of 1903 provided for a second naval station in Bahia Honda Bay, it would appear that the right to this naval station has been abandoned. Instead of the direct obligation of Cuba to undertake the sanitation of the cities of the island, the two governments agree reciprocally in Article 4 of the new treaty simply to suspend communications with such ports or parts of territory as may be considered advisable upon the outbreak of contagious disease in either country.

Coming back to the realities of the situation under the new treaty, Cubans must now for the first time assume the full responsibilities of government after thirty years of American tutelage. The United States will no longer be the official mentor and adviser. A whole gallery of nations will watch the plays of the doughty little country, but none with greater pride or sympathy than North America.

It will be understood, of course, that the elimination of the Platt Amendment is not a panacea for Cuba's ills nor a foolscap guaranty of improvement. Her troubles are as much economic as political. Her political troubles are 
not external but internal, but her economic problems are external as well as internal. If Cuba is to prosper, she must have a government sufficient to maintain law and order and a rehabilitation of the sugar industry, which depends upon a world market for approximately 3,000,000 long tons annually. It is expected the latter will be aided by recent legislation of Congress 3 and the proposed trade agreement by which Cuba may obtain better preferential treatment, particularly for sugar.

The great interest of the United States still remains in the Caribbean area, namely, the Panama Canal, which is a vital link in her national defense. Around this center must necessarily revolve the American political and commercial policies. They need not be proclaimed in formal treaties or understandings for the enlightenment of the world, for they are the necessary and obvious sequences of an actuality. It is clear that the United States, acting under the Monroe Doctrine and the rights of international law, will brook no situation in the Caribbean which menaces her national defense. ${ }^{4}$ It is an inevitable corollary that this region will always be a sphere of influence of the United States.

But the clouds of apprehension as to the ulterior motives of the United States have cleared away. By the action of the United States in establishing the independence of Cuba after the Spanish-American War, by its intervention under the Platt Amendment in 1906-1909 and subsequent withdrawal, by its settlement of the Isle of Pines matter in favor of Cuba, and by the present surrender of the Platt Amendment, it has been shown that the United States has no designs upon the island. The whole history of the United States in Cuba has been one of magnanimity toward a small country, unexampled in the annals of international relations, and sufficient, it is believed, to satisfy the most delicate sensibilities. It is an invitation for their full-hearted cooperation.

LESTER H. WOOLSEY

THE ARMS EMBARGO AGAINST BOLIVIA AND PARAGUAY

The war between Bolivia and Paraguay in the Gran Chaco region, which has been proceeding continuously for two full years, is not only a major scandal in international relations as between the parties themselves, but an affront to fundamental principles of law and order within the community of nations at large. For the issues involved in the conflict have none of the political, economic and social complexity presented by the conditions in the Far East under which the machinery of international settlement recently broke down. Is the issue between the belligerents in the Chaco one of disputed boundary lines? If so, the processes of arbitration are admittedly suited to such a question. Is the issue more fundamental than a boundary dispute, involving the urgent need of one of the belligerents for an outlet to the sea? If so, international law has numerous precedents for the grant of

Act approved May 9, 1934, and proclamation of same date reducing the duty on sugar.

4 Compare the reservations of the U. S. to the Montevideo Antiwar Treaty and the Convention on Rights and Duties of States. 